(Bauer \& Glutz von Botzheim 1968, Merilä \& Ochtonen 1987, Källander 2005). Gräsand Anas platyrhynchos, bläsand $A$. penelope och sothöna Fulica atra utnyttjar uppvirvlat material på vattenytan, medan knipa Bucephala clanga, vigg Aythya fuligula och brunand Aythya ferina dyker in under de födosökande svanarna. En nyligen publicerad experimentell studie (Gyimesi m.fl. 2012) har visat att brunänder härigenom kan fördubbla sitt näringsintag per tidsenhet. I en studie (Källander 2005) hade ungefär häften av 583 sångsvanar och mindre sångsvanar associerade simfåglar (nästan uteslutande bläsänder) mot endast 2,6\% av 1381 knölsvanar C. olor. Denna skillnad tycks bero på svanarternas olika förosöksmetod: sångsvanen och mindre sångsvanen "fot-paddlar" i bottenmaterialet för att exponera lagringsknölar på borstnatens Potamogeton pectinatus rhizomer, medan knölsvanen sällan tycks "fot-paddla" och lever av andra submersa växter (Bauer \& Glutz von Blotzheim 1968). Det var därför något förvånande när jag $\mathrm{i}$ augusti 2012 fann en grupp sothöns, vilken nära associerade sig med ett knölsvanpar och pickade uppvirvlat material från ytan (Figur 1). Antalet sothöns i anslutning till en svan varierade, fåglarna höll sig företrädesvis bakom svanarna och simmade undan en smula när svanarna drog upp halsen, blott för att omedelbart simma fram igen när svanhalsen på nytt försvann under ytan. De hundratals timmar jag räknat och observerat simfåglar på Krankesjön under de senaste åtta åren utan att tidigare ha noterat någon kommensal associering med knölsvan tyder på att den sannolikt är relativt ovanlig.

Under studier av kommensalt utnyttjande av svanar på nordsidan av Falsterbohalvön hösten 1994, upptäcktes att bläsänder också i viss utsträckning utnyttjade kanadagäss Branta canadensis. Sålunda hade den 19 november 23 av 350 (6,3\%) kanadagäss bläsänder, som utnyttjade dem. Iakttagelsen är en aning förvånande, eftersom kanadagäss verkar födosöka mer som knölsvan än som sångsvan och mindre sångsvan, men bläsänder har också rapporterats utnyttja prutgäss Branta bernicla (Bauer \& Glutz von Blotzheim 1968).

Hans Källander, Biologiska institutionen, Lunds Universitet, Ekologihuset, SE-223 62 Lund, Sweden.E-mail:hans.kallander@telia.com

\section{Northern Wheatear Oenanthe oenanthe prey on newt}

\author{
Stenskvätta Oenanthe oenanthe tar \\ salamander som byte
}

\section{MICHAŁ CIACH}

The diet of Northern Wheatear Oenanthe oenanthe is composed with invertebrates - mainly arthropods (insects and spiders), earthworms, and snails - and a much smaller fraction of plant material. Information on vertebrate prey is exceptional (Cramp 1998) and only a single record of Sand Lizard Lacerta agilis intake has been noted (Grössler 1959).

On 7 April 2012 in the Ustrzyki Dolne town (Carpathians, SE Poland) I saw a unique behaviour of Northern Wheatear. On a meadow a group of four birds (three females and one male) were foraging. While watched, one of the females attacked a newt (Figue 1.). The bird stroke the prey against the ground several times, handling its head or tail (Figure 2.). Having difficulties in prey managing (or due to observer presence), the bird flew ca. 200 meters with the prey in its bill and landed on the ground, where it finished the consumption. The entire time of prey handling and consumption was about five minutes. The observation was conducted at noon, in good, cloudless and windless weather.

The observation described in this note is the second record of a Northern Wheatear foraging on a vertebrate and also the first record an amphibian was seen to be part of the diet of this species. Four species of newts are recorded in southern Poland (Juszczyk 1987, Głowaciński \& Rafiński 2003). The prey species was difficult to determine. However, based on size and coloration it probably was Common Newt Lissotriton vulgaris or Carpathian Newt Lissotriton montandoni.

The diet of several Wheatear species occurring in arid or semi-arid regions may occasionally include vertebrates - small lizards and geckos (Cramp 1998). However, to prey on newt by Northern Wheatear is surprising in light of what is known about the diet of this species. Northern Wheatears arrive in Poland at the end of March and singles or small groups of birds are seen in a variety of habitats, e.g. on plowing fields and meadows (Tomiałojć \& Stawarczyk 2003). The use of vertebrates by Northern Wheatear may be related to the cold spring weather, when ectothermic (coldblooded) species leaving hibernation shelters are 


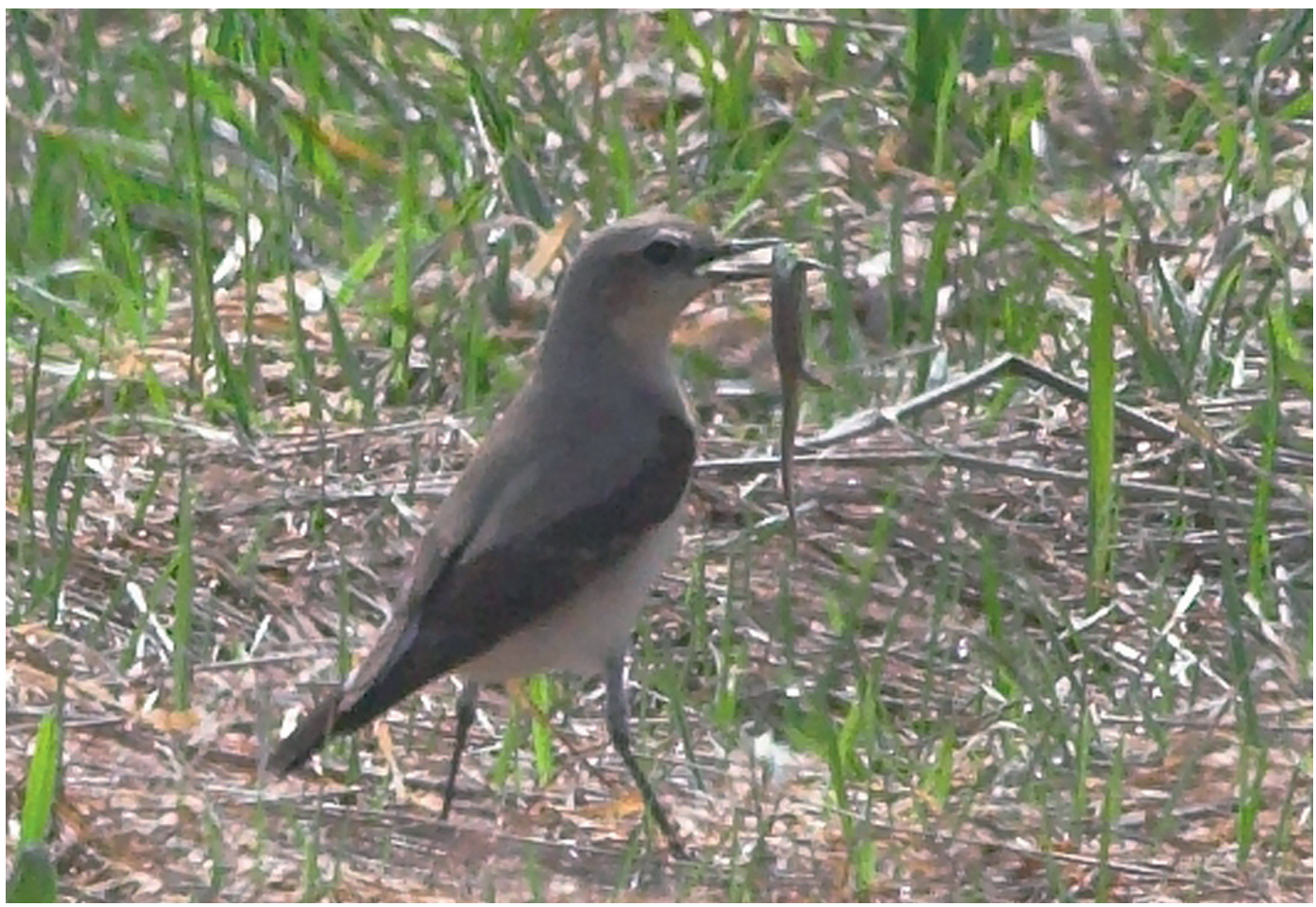

Figure 1. Northern Wheatear Oenanthe oenanthe prey on newt (7 April 2012, Carpathians, SE Poland).

Stenskvätta fångar salamander.

easy to catch. My observation indicates that the Northern Wheatear is an opportunistic forager, having broader dietary niche than suspected.

\section{References}

Cramp, S. 1998. The complete birds of Western Palearctic on $C D$-ROM. Version 1.0. Oxford University Press, Oxford.

Głowaciński, Z. \& Rafiński, J. (eds). 2003. Atlas of the Amphibians and Reptiles of Poland. Status - distribution - conservation. Biblioteka Monitoringu Środowiska, Warszawa-Kraków. (in Polish with English summary)

Grössler, K. 1959. Steinschmätzer (Oenanthe oenanthe) erbeutet Eidechse. Ornithologische Mitteilungen 11: 208.

Juszczyk, W. 1987. Plazy i gady krajowe. PWN, Warszawa. (in Polish)

Tomiałojć, L. \& Stawarczyk, T. 2003. The avifauna of Poland. Distribution, numbers and trends. PTPP ,,pro Natura". Wrocław, Poland. (in Polish with English summary)

\section{Sammanfattning}

Stenskvättans föda utgörs av främst av insekter, spindlar, maskar och sniglar och en ringa del växtmaterial. Att stenskvättor tar ryggradsdjur hör till undantagen. Den 7 april 2012 såg jag dock ett unikt beteende. På en äng födosökte tre honor och en hane och medan jag följde fåglarna tog en av honorna en salamander (Figur 1). Hon slog bytet mot marken flera gånger medan hon höll det $\mathrm{i}$ huvudet eller stjärten (Figur 2). På grund av problemen med bytet eller på grund av min närvaro flög hon iväg ungefär två hundra meter med salamandern i näbben. När hon landat igen svalde hon bytet. Hela processen tog ungefär fem minuter. Stenskvättearter som lever i torra områden livnär sig mera regelbundet på ödlor och geckoer, men att en vanlig stenskvätta tar en salamander är oväntat med hänsyn till vad som är känt om dieten. Min observation är bara det andra rapporterade fallet.

Michat Ciach, Department of Zoology and Wildlife Management, Forest Biodiversity Institute, $\mathrm{Fa}$ culty of Forestry, University of Agriculture, al. 29 Listopada 46, 31 - 425 Kraków, Poland. E-mail: michal.ciach@ur.krakow.pl 

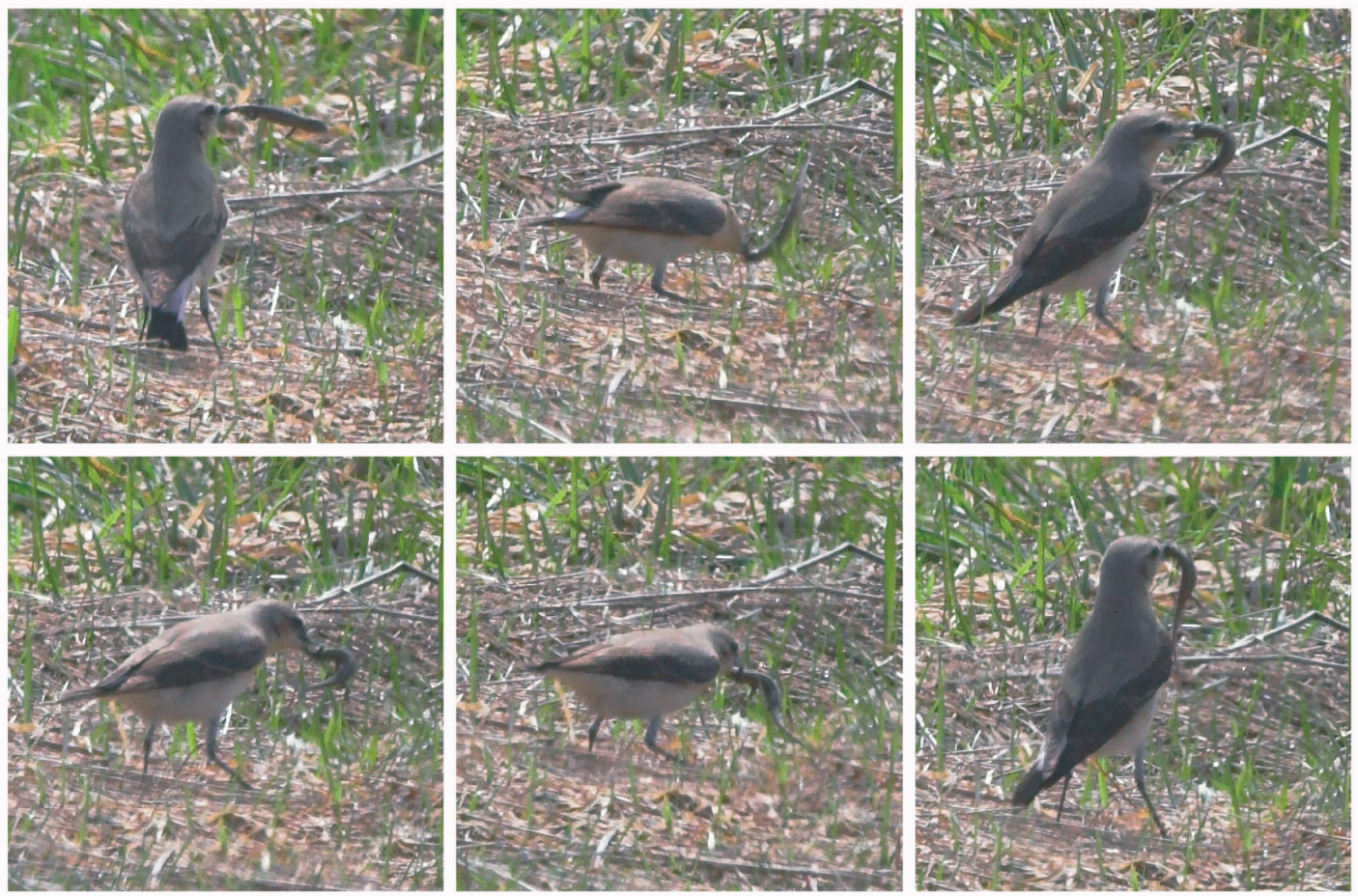

Figure 2. Handling the newt by Northern Wheatear Oenanthe oenanthe (7 April 2012, Carpathians, SE Poland).

Stenskvätta hanterar salamander

\section{Rasen hornemanni av snösiska Carduelis hornemanni aldrig säkert anträffad i Sverige}

\author{
Subspecies hornemanni of Arctic \\ Redpoll Carduelis hornemanni never \\ recorded in Sweden
}

\section{LARS SVENSSON}

Snösiskan Carduelis hornemanni förekommer i två olika underarter, den mindre exilipes som häckar i nordligaste Fennoskandien och vidare österut i norra Ryssland och Sibirien, och som uppträder sällsynt men relativt regelbundet vintertid i södra och mellersta Sverige, och den mer storvuxna hornemanni som häckar på norra Grönland och i delar av arktiska Nordamerika, men som av allt att döma även häckar på norra Island. På Island betecknas den dock av hävd som en extremt ljus lokal gråsiska (Carduelis flammea 'islandica', ljus morf), men dessa ljusa isländska fåglar skiljer sig inte från snösiskor i andra trakter mer än i så måtto att de är intermediära i storlek mellan exilipes och hornemanni (Shirihai \& Svensson in prep.). Rasen hornemanni är stann- eller strykfågel och gör blott kortare vintertida förflyttningar, men den är rätt regelbundet anträffad i Skottland som tillfällig besökare under vinterhalvåret, och vissa år i större antal än annars.

Av underarten hornemanni finns ett svenskt fynd rapporterat i litteraturen, en ung hane insamlad av Sigvard Sjöberg den 27 april 1934 i Gällivare, Lule lappmark (Lundevall 1941). Exemplaret förvaras som skinn på Naturhistoriska Riksmuseet i Stockholm (NRM S 1). Det upptäcktes 1941 av Lundevall vid genomgång av Riksmuseets samling av grå- och snösiskor och sändes senare samma år till Finn Salomonsen i Köpenhamn för verifiering, vilket skedde efter jämförelse med Köpenhamnsmuseets samling.

Fågeln är stor och har lång vinge, $82 \mathrm{~mm}$, men ser annars ut som en gråsiska. Lundevalls beskrivning innehåller ingen närmare analys av hur gråoch snösiskor skulle skilja sig åt eller varför denna individ måste vara en hornemanni. Där står bara att 